\title{
ANALISIS FAKTOR-FAKTOR YANG MEMPENGARUHI TINGKAT KONSUMSI AIR PDAM TERHADAP PELANGGAN SEKTOR RUMAH TANGGA DAN NON RUMAH TANGGA DI KOTA LAMONGAN
}

\author{
*( Nurul Badriyah \\ Prodi Manajemen, Fakultas Ekonomi, Universitas Islam Lamongan \\ $\mathrm{Jl}$. Veteran No.53A Lamongan \\ Telp. ( 0322 ) 324706, Faks. ( 0322 ) 324706 \\ Email :jpim.unisla@gmail.com
}

\begin{abstract}
ABSTRAK
Air bersih di perlukan untuk meningkatkan kesejahteraan masyarakat. Oleh karena itu, pemakaian air bersih dalam suatu negara sering dianggap salah satu tolak ukur taraf kemampuan rakyatnya. Tujuan dalam penelitian yaitu: (1) Untuk mengetahui faktor harga air,pendapatan perkapita,jumlah penduduk mempunyai pengaruh secara parsial terhadap tingkat konsumsi air PDAM (2) Untuk mengetahui faktor harga air,pendapatan perkapita,jumlah penduduk mempunyai pengaruh secara simultan terhadap tingkat konsumsi air PDAM (3) Untuk mengetahui dan menganalisis di antara harga air, pendapatan perkapita, dan jumlah penduduk yang mempunyai pengaruh paling dominan terhadap tingkat konsumsi air PDAM. Hasil regresi linier berganda diperoleh persamaan $\left(Y=1,043+0,287 X_{1}+0,271 X_{2}+0,347 X_{3}\right)$. Perhitungan korelasi berganda sebesar 0,836. Hasil determinasi menunjukkan variabel bebas terhadap variabel terikatnya memberikan kontribusi sebesar 69,9\%. hasil uji $t$ diperoleh nilai $t$ hitung $X_{1}(2,485), X_{2}(2,131), X_{3}(2,664)>t$ tabel $(1,985)$. Hasil uji $F F_{\text {hitung }}(71,634)>F_{\text {tabel }}(2,699)$, Dari hasil analisi disimpulkan bahwa variabel bebas (harga, pendapatan perkapita dan jumlah penduduk) mempunyai pengaruh terhadap sektor rumah tangga dan non sektor rumah tangga. Maka perusahaan diharapkan selalu mensurvei jumlah penduduk di kota Lamongan.
\end{abstract}

Kata kunci : Harga, Pendapatan Perkapita, Jumlah Penduduk dan Tingkat Konsumsi

\section{PENDAHULUAN}

Melihat kondisi yang ada pada saat ini yaitu rendahnya tingkat konsumsi air bersih PDAM dalam memenuhi kebutuhan masyarakat terhadap air bersih, maka sangat diperlukan suatu usaha dalam meningkatkan konsumsi air bersih PDAM salah satunya dengan beberapa strategi ataupun rencana yang dapat dilakukan oleh pemerintah dalam peningkatan penggunaan air PDAM.
Rata-rata besarnya jumlah konsumsi air bersih PDAM di suatu wilayah di dominasi oleh konsumsi air bersih rumah tangga. pada saat ini air bersih PDAM masih didominasi oleh pelanggan rumah tangga. Hal ini terjadi dikarenakan rumah tangga sebagai tempat tinggal penduduk dimana seluruh kegiatan setiap waktunya dilakukan di perumahan. Pemenuhan kebutuhan air bersih 
untuk golongan rumah tangga memegang peranan penting dalam menjaga produktivitas nasional secara keseluruhan (Kantor Menteri Negara Lingkungan Hidup, 2013:510). Harga jual mungkin merupakan elemen dalam program pemasaran yang paling mudah diubah sedangkan fitur produk,saluran pemasaran dan juga program promosi akan memakan waktu lebih lama untuk dapat diubah. Harga jual produk juga mampu mengkomunikasikan paada pasar tentang nilai positioning yang dimaksudkan oleh perusahaan atau brand-nya

(Gunawan,2010:209)

Pendapatan perkapita juga sering digunakan sebagai indikator pembangunan suatu negara untuk membedakan tingkat kemajuan ekonomi antara negara-negara maju dengan negara sedang berkembang. Dengan kata lain selain pendapatan per kapita bisa memberikan gambaran tentang laju pertumbuhan kesejahteraan masyarakat di berbagai negara juga dapat menggambarkan perubahan corak perbedaan tingkat kesejahteraan masyarakat yang sudah terjadi diantara berbagai negara.( Tjiptono,2012:178)

Didasarkan atas beberapa kriteria, di dalam mengelompokkan negaranegara sebagai negara maju atau berkembang. Ketujuh indikator tersebut adalah:

1) Pendapatan Nasional Perkapita (Gross National Product/GNP)

GNP sebagai patokan yaitu dengan cara membagi antara jumlah keseluruhan pendatan negara pertahun dengan jumlah seluruh penduduk negara tersebut.Apabila hasil baginya lebih dari 10.000 dolar Amerika Serikat (U.S \$ 10.000), maka negara tersebut dapat dikelompokkan sebagai negara maju.Sedangkan apabila kurang dari 80 dolar Amerika Serikat (U.S \$ 80), maka dikelompokkan ke dalam negara sedang berkembang.

2) Struktur mata pencaarian dari angkatan kerja.

Jika prosentase angkata kerja pada sektor yang memproduksi bahan makanan pokok lebih besar, maka negara tersebut dikelompokkan sebagai negara sedang berkembang.Sedangkan apabila prosentase angkata kerja pada sektor jasa lebih besar, maka negaratersebut dikelompokkan sebagai negara maju.

3) Produktifitas per-tenaga kerja.

Prouktivitas tenaga perkerja ditentukan dengan cara keseluruhan produksi selama satu tahun dibagi dengan jumlah seluruh angkatan kerja. Apabila produktivitas perangkatan kerja tinggi maka tergolong negara maju, demikian sebaliknya.

4) Pengunaan energi per-orang.

Jika tingkat penggunaan tenaga listrik dan bentuk energi lainnya nya tinggi, maka tingkat perkembangan nasionalnya tinggi (negara maju). Namun demikian, indikator ini tidak bersifat mutlak karena bergantung pada kondisi iklim negara yang bersangkutan. 
5) Fasilitas transportasi dan komunikasi

Parameter ini ditentukan dengan cara mengetahui indeks perkapita dari pengukuran jalan kereta api, jalan raya, hubungan udara, telepon, radio, televisi, dan sebaginya. Jika indeksnya makin tinggi, maka makin tinggi pula tingkat perkembangan nasional negara tersebut.

6) Pengunaan metal yang telah diolah.

Hal ini ditentukan oleh jumlah bahan-bahan metal seperti : besi, baja, tembaga, alumunium dan logam lainnya yang digunakan penduduk selama setahun tertentu. Semakin banyak jumlah yang digunakan, maka semakin tinggi tingkat perkembangan nasional negara tersebut. Indonesia yang merupakan negara kepulauan, memiliki penduduk dari pelbagai etnis adat kebudayaan. Hal ini menjadikan setiap pulau di Indonesia memiliki karakteristik yang berbeda-beda, baik dari segi fisik, logat bahasa, kebiasaan, dan adat yang berlaku. Keanekaragaman ini menjadikan Indonesia tidak hanya kaya akan sumber daya alam, melainkan juga kaya sumber daya manusia beserta kebudayaan. Kebudayaan ini merupakan salah satu daya tarik untuk menarik minat para turis mancanegara, sehingga meningkatkan pendapatan negara.

Tingkat pelayanan air bersih perkotaan saat ini masih relatif rendah, pada akhir tahun 2010 hanya $36 \%$ penduduk perkotaan penduduk indonesia yang dilayani oleh sistem perpipaan, baik melalui keran umum. Selain sebagai tambahan sebanyak 350.000 sambungan melayani melayani wilayah perkotaan, fasilitas komersial dan sosial lainnya (air minum no.87/thn .XXI jan 2014).

Selama ini penyediaan sarana air bersih diperkotaan dapat berasal dari air bersih yang dilayani oleh PDAM, memanfaatkan air sumur serta memmbeli dari penjual air keliling. Air baku yang diolah PDAM menjadi air bersih bersumber dari permukaan, mata air dan air tanah. Dari segi kualitas, air baku tersebut mempuyai beberapa perbedaan. Air tanah dan mata air mempunyai kualitas (baku mutu air) relatif baik, sehingga sistem pengelolahannya lebih sederhana, sedangkan air permukaan pada umumnya mudah tercemar, karena sungai - sungai yang merupakan sumber air baku cenderung digunakan sebagai tempat pembuangan sampah, limbah rumah tangga dan industri. Sebagai akibatnya, kualitas air baku menurun dan membutukan pengolahan yang lebih baik agar hasilnya dapat mencapai standar kualitas air bersih yang layak guna.

Faktor yang mempengauhi pasokan (supply) air bersih yang dilakukan oleh PDAM terbagi menjadi dua, yaitu faktor ekternal dan faktor internal (pedoman penyusunan Corporate Plan,2000).

a) Faktor ekternal, yaitu kondisi dan lingkungan usaha yang meliputi:

- Profil tata ruang wilayah pelayanan PDAM. 
- Latar belakang sosial ekonomi yang mencakup (1) jumlah, penyebaran dan laju pertumuhan penduduk, (2) tingkat pendidikan dan mata pencaharian penduduk, (3) aktivitas dan penyebaran berbagai sektor perekonomian kota, (4) pendapatan rumah tangga, dan (5) struktur dan tren pertumbuhan PBRB.

- Rencana tata ruang dan potensi pertumbuhan kota.

- Dukungan pemerintah daerah dan/atau DPRD

- Kebijakan sektoral dan regional mengenai pengelolaan sistem penyediaan air bersih

- Kebijakan pemerintah dan lembaga-lembaga keuangan internasional mengenai pendanaan proyek-proyek infrastruktur publik

- Pengaturan dan perlindungan sumber air baku.

- Organisasi dan peraturan perlindungan konsumen

b) Faktor internal, yaitu kompetensi serta kapasitas strategis sumber daya yang dimiliki perusahaan, yang meliputi:

- Kondisi sistem yang ada, meliputi sumber air baku, unit produksi, sistem transmisi dan distribusi, dan tingkat kehilangan air (unaccounted for water/ non revene water).

- Final Engineering Design/ Detail Engineering Design, program pengembangan atau Capitol Investment Program yang sudah disepakati dan/atau sedang berjalan

- Kebijakan tarif air dan pembeberan biaya pemasangan baru

- Sistem akuntansi, penyusunan serta pengendalian anggaran

- Pelaksanaan fungsi-fungsi manajemen

- Kondisi (loyalitas, efisiensi dan kapasitas kerja) sumber daya manusia

- Kondisi keuangan, meliputi profitabilitas, cash flow, neraca serta indikatot dan rasio-rasio keuangan

Konsumsi merupakan perbelanjaan yang dilakukan oleh rumah tangga atas barang-barang akhir atau jasa-jasa dengan tujuan untuk memenuhi kebutuhan. Menurut Keynes dalam teori konsumsi Absolute Income Hypothesis mengatakan bahwa faktor utama yang menentukan konsumsi suatu rumah tangga adalah pendapatannya (Sukirno: 2012). Pada pendapatan yang sangat rendah, konsumsi akan melebihi pendapatan dan konsumsi yang melebihi pendapatan ini akan dibiayai oleh tabungannya pada masa lalu atau dari pinjaman. Sedangkan pada tingkat pendapatan yang tinggi, tidak semua pendapatan yang diterima digunakan untuk konsumsi tetapi ada sebagian pendapatannya untuk ditabung. Sehingga fungsi konsumsi dalam hal ini merupakan persamaan yang menunjukkan hubungan antara tingkat konsumsi rumah tangga dengan pendapatan disposibel. Secara 
matematis dapat dirumuskan sebagai berikut:

$$
\mathrm{C}=\mathrm{a}+\mathrm{b} \mathrm{Y}_{\mathrm{d}}
$$

Dimana $\mathrm{C}$ adalah menggambarkan nilai konsumsi yang dilakukan oleh rumah tangga, (a) adalah konsumsi otonomi, yaitu tingkat yang tidak dipengaruhi oleh pendapatan nasional, (b) adalah kecondongan konsumsi marginal (MPC), yaitu proporsi antara pertambahan konsumsi dengan pertambahan pendapatan dan $\mathrm{Y}_{\mathrm{d}}$ adalah pendapatan disposibel.

Rumusan masalah pada penelitian ini adalah

1. Apakah faktor-faktor (Harga, Pendapatan Perkapita, dan Jumlah Penduduk) mempunyai pengaruh secara parsial terhadap pelanggan sektor rumah tangga dan non rumah tangga di kota Lamongan?

2. Apakah faktor-faktor (Harga, Pendapatan Perkapita, dan Jumlah Penduduk) mempunyai pengaruh secara simultan terhadap pelanggan sektor rumah tangga dan non sektor rumah tangga di kota Lamongan?

3. Manakah di antara Harga Air, Pendapatan Perkapita dan Jumlah Penduduk yang mempunyai pengaruh paling dominan terhadap pelanggan sektor rumah tangga dan non sektor rumah tangga di kota Lamongan?

Adapun tujuan penelitian ini adalah untuk mengetahui Apakah faktor harga air,pendapatan perkapita,jumlah penduduk mempunyai pengaruh secara parsial terhadap tingkat konsumsi air PDAM terhadap pelanggan sektor rumah tangga dan non sektor rumah tangga di kota lamongan., Untuk mengetahui Apakah faktor harga air, pendapatan perkapita, jumlah penduduk mempunyai pengaruh secara simultan terhadap tingkat konsumsi air PDAM terhadap pelanggan sektor rumah tangga dan non sektor rumah tangga di kota lamongan. Untuk mengetahui dan menganalisis manakah di antara harga air, pendapatan perkapita, dan jumlah penduduk yang mempunyai pengaruh paling dominan terhadap tingkat konsumsi air PDAM .

\section{LANDASAN TEORI}

Harga memiliki peranan yang sangat penting dalam mempengaruhi keputusan konsumen dalam membeli produk, sehingga sangat menentukan keberhasilan pemasaran suatu produk. Definisi harga menurut Kotler dan Armstrong (2001: 439) adalah sejumlah uang yang dibebankan atas suatu produk atau jasa, atau jumlah dari nilai yang ditukar konsumen atas manfaat-manfaat karena memiliki atau menggunakan produk atau jasa tersebut. Pendapatan per kapita, baik dalam ukuran GNP maupun PDB merupakan salah satu indikaor makroekonomi yang telah lama digunakan untuk mengukur pertumbuhan ekonomi. Dalam perspektif makroekonomi, indikator ini merupakan bagian kesejahteraan manusia yang dapat diukur, sehingga dapat menggambarkan kesejahteraan dan kemakmuran masyarakat. Tampaknya pendapatan per kapita telah menjadi indikator makroekonomi yang tidak bisa diabaikan, walaupun memiliki 
beberapa kelemahan. Sehingga pertumbuhan pendapatan nasional, selama ini, telah dijadikan tujuan pembangunan di negara-negara dunia ketiga. Seolah-olah ada asumsi bahwa kesejahteraan dan kemakmuran masyarakat secara otomatis ditunjukkan oleh adanya peningkatan pendapatan nasional (pertumbuhan ekonomi). Walaupun demikian, beberapa ahli menganggap penggunaan indikator ini mengabaikan pola distribusi pendapatan nasional. Indikator ini tidak mengukur distribusi pendapatan dan pemerataan kesejahteraan, termasuk pemerataan akses terhadap sumber daya ekonomi.

Pengeluaran konsumsi terdiri dari konsumsi pemerintah (government consumption) dan konsumsi rumah tangga (household consumption/private consumption). Factor-faktor yang mempengaruhi besarnya pengeluaran konsumsi rumah tangga, antara lain :

1. Faktor Ekonomi

Empat faktor yang menentukan tingkat konsumsi, yaitu :

a. Pendapatan Rumah Tangga ( Household Income )

Pendapatan rumah tangga amat besar pengaruhnya terhadap tingkat konsumsi. Biasanya makin baik tingkat pendapatan, tongkat konsumsi makin tinggi. Karena ketika tingkat pendapatan meningkat, kemampuan rumah tangga untuk membeli aneka kebutuhan konsumsi menjadi semakin besar atau mungkin juga pola hidup menjadi semakin konsumtif, setidak-tidaknya semakin menuntut kualitas yang baik.

b. Kekayaan Rumah Tangga ( Household Wealth )

Tercakup dalam pengertian kekayaaan rumah tangga adalah kekayaan rill (rumah, tanah, dan mobil) dan financial (deposito berjangka, saham, dan surat-surat berharga). Kekayaan tersebut dapat meningkatkan konsumsi, karena menambah pendapatan disposable.

c. Tingkat Bunga (Interest Rate )

Tingkat bunga yang tinggi dapat mengurangi keinginan konsumsi. Dengan tingkat bunga yang tinggi, maka biaya ekonomi (opportunity cost) dari kegiatan konsumsi akan semakin maha. Bagi mereka yang ingin mengonsumsi dengan berutang dahulu, misalnya dengan meminjam dari bankatau menggunakan kartu kredit, biaya bunga semakin mahal, sehingga lebih baik menunda/mengurangi konsumsi.

d. Perkiraan Tentang Masa Depan (Household Expectation About The Future)

Faktor-faktor internal yang dipergunakan untuk memperkirakan prospek masa depan rumah tangga antara lain pekerjaan, karier dan gaji yang menjanjikan, banyak anggota keluarga yang telah bekerja.

Sedangkan faktor-faktor eksternal yang mempengaruhi antara lain 
kondisi perekonomian domestic dan internasional, jenis-jenis dan arah kebijakan ekonomi yang dijalankan pemerintah.

2. Faktor Demografi

a. Jumlah Penduduk

Jumlah penduduk yang banyak akan memperbesar pengeluaran konsumsi secara menyeluruh, walaupun pengeluaran rata-rata per orang atau per keluarga relative rendah. Pengeluaran konsumsi suatu negara akan sangat besar, bila jumlah penduduk sangat banyak dan pendapatan per kapita sangat tinggi.

b. Komposisi Penduduk

Pengaruh komposisi penduduk terhadap tingkat konsumsi, antara lain:

- Makin banyak penduduk yang berusia kerja atua produktif (1564 tahun), makin besar tingkat konsumsi. Sebab makin banyak penduduk yang bekerja, penghasilan juga makin besar.

- Makin tinggi tingkat pendidikan masyarakat, tingkat konsumsinya juga makin tinggi, sebab pada saat seseorang atau suatu keluarga makin berpendidikan tinggi maka kebutuhan hidupnya makin banyak.

- Makin banyak penduduk yang tinggal di wilayah perkotaan (urban), pengeluaran konsumsi juga semakin tinggi. Sebab umumnya pola hidup masyarakat perkotaan lebih konsumtif disbanding masyarakat pedesaan.

3. Faktor-faktor Non Ekonomi

Factor-faktor non-ekonomi yang paling berpengaruh terhadap besarnya konsumsi adalah faktor social budaya masyarakat. Misalnya saja, berubahnya pola kebiasaan makan, perubahan etika dan tata nilai karena ingin meniru kelompok masyarakat lain yang dianggap lebih hebat/ideal.

\section{METODE PENELITIAN}

Jenis penelitian yang digunakan adalah deskriptif kuantitatif. Data kuantitatif adalah data berupa angka. Sesuai dengan bentuknya, data kuantitatif dapat diolah atau dianalisis dengan menggunakan teknik perhitungan statistik. (Ir. Syofian, 2014:17) dan Pada dasarnya, penelitian dilaksanakan untuk menemukan solusi atas masalah yang sedang terjadi. Dalam pelaksanaanya, dapat digunakan metode penelitian. Metode penelitian merupakan cara ilmiah untuk mendapatkan data dengan tujuan dan kegunaan tertentu (Sugiyono: 2014). Metode penelitian dibagi menjadi dua jenis yaitu penelitian kuantitatif dan penelitian kualitatif. Metode penelitian kuantitatif adalah metode penelitian yang berlandaskan pada filsafat positivisme, digunakan untuk meneliti pada populasi atau sampel tertentu, pengumpulan data menggunakan instrumen penelitian, analisis data bersifat kuantitatif/statistik, dengan tujuan untuk menguji hipotesis yang telah ditetapkan. Sedangkan metode penelitian kualitatif adalah metode penelitian yang berlandaskan pada filsafat pospositivime, digunakan untuk meneliti objek yang alamiah, teknik pengambilan data dilakukan secara triangulasi, analisis data bersifat induktif/kualitatif yang lebih menekankan makna dari pada generalisasi. Metode penelitian kuantitatif mencakup eksperimen dan 
survei, namun dalam hal ini hanya membahas metode penelitian survei. Penelitian survey merupakan penelitian kuantitatif dengan menggunakan pertanyaan terstruktur yang sama pada setiap orang, kemudian semua jawaban yang diperoleh peneliti dicatat, diolah, dan dianalisis. Pertanyaan terstruktur disebut kuesioner. Kuesioner berisi pertanyaan-pertanyaan yang akan diberikan kepada responden untuk mengukur variabel-variabel, berhubungan diantara variabel yang ada, serta dapat berupa pengalaman dan pendapat dari responden. Metode survei biasanya digunakan untuk mendapatkan data dari tempat tertentu yang alamiah, namun peneliti melakukan perlakuan dalam pengumpulan data (kuesioner, test, wawancara, dan sebagainya), perlakuan yang diberikan tidak sama pada eksperimen (Sugiyono :2014).

\section{HASIL PENELITIAN DAN PEMBAHASAN}

1. Uji Validitas

Pengujian validitas menggunakan product moment pada tingkat signifikan $95 \%$ ( $\alpha=0,05$ Butir pernyataan di katakan valid ), jika skor item berkorelasi secara signifikan dengan total skor yang ditunjukkan dari nilai rhitung > rtabel .

Tabel 1.

Hasil Uji Validitas

\begin{tabular}{|c|c|c|c|c|c|}
\hline No & $\begin{array}{c}\text { Variab } \\
\text { el }\end{array}$ & $\begin{array}{l}\text { No } \\
\text { Item }\end{array}$ & $\mathrm{R}$ & $\begin{array}{l}\text { Sig (2- } \\
\text { tailed) }\end{array}$ & $\begin{array}{r}\text { Ketera } \\
\text { ngan }\end{array}$ \\
\hline \multirow[t]{2}{*}{1} & \multirow{2}{*}{$\begin{array}{l}\text { Harga } \\
\left(\mathrm{X}_{1}\right)\end{array}$} & $\mathrm{X}_{1.1}$ & 0.874 & 0.000 & Valid \\
\hline & & $\mathrm{X}_{1.2}$ & 0.864 & 0.000 & Valid \\
\hline \multirow[t]{2}{*}{2} & \multirow{2}{*}{$\begin{array}{c}\text { Pendap } \\
\text { atan } \\
\text { Perkap } \\
\text { ita }\left(\mathrm{X}_{2}\right)\end{array}$} & $\mathrm{X}_{2.1}$ & 0.826 & 0.000 & Valid \\
\hline & & $\mathrm{X}_{2.2}$ & 0.878 & 0.000 & Valid \\
\hline \multirow[t]{2}{*}{3} & \multirow{2}{*}{$\begin{array}{c}\text { Jumlah } \\
\text { Pendu }\end{array}$} & $X_{3.1}$ & 0.840 & 0.000 & Valid \\
\hline & & $\mathrm{X}_{3.2}$ & 0.858 & 0.000 & Valid \\
\hline
\end{tabular}

\begin{tabular}{|r|l|l|l|l|l|}
\hline & $\begin{array}{l}\text { duk } \\
\left(\mathrm{X}_{3}\right)\end{array}$ & & & & \\
\hline 4 & $\begin{array}{l}\text { Sektor } \\
\text { Rumah } \\
\text { Tangg } \\
\text { a dan } \\
\text { Non } \\
\text { Rumah } \\
\text { Tangg } \\
\text { a (Y) }\end{array}$ & $\mathrm{X}_{\mathrm{Y} .1}$ & 0.981 & 0.000 & Valid \\
\cline { 2 - 5 } & & 0.980 & 0.000 & Valid \\
\hline
\end{tabular}

Sumber : Output SPSS 17

2. Uji Reabilitas

Table 2.

Hasil Uji Variabel

\begin{tabular}{|c|l|r|r|r|}
\hline No & Variabel & $\begin{array}{c}\text { Cronbach } \\
\text { Alpha }\end{array}$ & $\begin{array}{r}\text { Nilai } \\
\text { Kritis }\end{array}$ & Keterangan \\
\hline 1 & Harga $\left(\mathrm{X}_{1}\right)$ & 0.675 & 0.6 & Reliabel \\
\hline 2 & $\begin{array}{l}\text { Pendapatan } \\
\text { perkapita } \\
\left(\mathrm{X}_{2}\right)\end{array}$ & 0.620 & 0.6 & Reliabel \\
\hline 3 & $\begin{array}{l}\text { Jumlah } \\
\text { penduduk } \\
\left(\mathrm{X}_{3}\right)\end{array}$ & 0.612 & 0.6 & Reliabel \\
\hline 4 & $\begin{array}{c}\text { Sektor } \\
\text { rumah } \\
\text { tangga dan } \\
\text { sector non } \\
\text { rumah } \\
\text { tangga (Y) }\end{array}$ & 0.960 & 0.6 & Reliabel \\
\hline
\end{tabular}

Sumber : Output SPSS 17

Dari tabel di atas, nilai Cronbach Alpha variabel bebas dan terikatnya, yaitu harga, pendapatan perkapita, dan jumlah penduduk lebih besar dari 0,6 dengan tingkat signifikan $\alpha=5$ $\%$ sehingga dapat disimpulkan bahwa instrumen dalam variabel bebas dan terikatnya realibel.

3. Analisis Regresi Liniear Berganda 
Table 3.

Hasil Uji Variabel Linier

Berganda

\begin{tabular}{|c|c|c|c|}
\hline Variabel & $\begin{array}{c}\text { Koefisien } \\
\text { Regresi }\end{array}$ & $\begin{array}{c}\text { Standar } \\
\text { Error }\end{array}$ & $\begin{array}{c}\mathrm{t} \text { - } \\
\text { hitung }\end{array}$ \\
\hline Harga $\left(\mathrm{X}_{1}\right)$ & 0,287 & 0,116 & 2,485 \\
\hline $\begin{array}{c}\text { Pendapatan } \\
\text { Perkapita }\left(\mathrm{X}_{2}\right)\end{array}$ & 0,271 & 0,127 & 2,131 \\
\hline $\begin{array}{c}\text { Jumlah } \\
\text { Penduduk }\left(\mathrm{X}_{3}\right)\end{array}$ & 0,347 & 0,130 & 2,664 \\
\hline $\begin{array}{l}\text { Konstanta } \\
\text { Koefisien Determinasi }\left(\mathrm{R}^{2}\right)\end{array}$ & $=1,043$ \\
Koefisien R & $=0,699$ \\
F-hitung & $=0,836$ \\
F-tabel & & $=71,634$ \\
t-tabel & & $=2,699$ \\
& & $=1,985$ \\
\hline
\end{tabular}

Sumber : Output SPSS 17

4. Analisis Korelasi Berganda

Tabel 4.

Hasil Uji Koefisien Korelasi antar

Variabel

Model Summary

\begin{tabular}{|c|c|c|c|c|}
\hline Model & $\mathrm{R}$ & $\begin{array}{c}\mathrm{R} \\
\text { Squar } \\
\mathrm{e}\end{array}$ & $\begin{array}{c}\text { Adjuste } \\
\mathrm{d} \mathrm{R} \\
\text { Square }\end{array}$ & $\begin{array}{c}\text { Std. Error } \\
\text { of the } \\
\text { Estimate }\end{array}$ \\
\hline 1 & .836 a & .699 & .690 & .73993 \\
\hline
\end{tabular}

Sumber : Output SPSS 17

a. Predictors: ( Constant), X3, $\mathrm{X} 1, \mathrm{X} 2$

Dari Tabel di atas dapat diketahui bahwa koefisien korelasi antara variabel bebas harga, pendapatan perkapita dan jumlah penduduk dengan variabel terikatnya sektor rumah tangga dan non rumah tangga adalah sebesar 0,836.

5. Analisis Koefisien Determinasi

Tabel 5.

Hasil Uji Regresi Linier Berganda Model Summary

\begin{tabular}{|c|c|c|c|c|}
\hline $\begin{array}{r}\text { Mod } \\
\text { el }\end{array}$ & $\mathrm{R}$ & $\begin{array}{r}\mathrm{R} \\
\text { Squ } \\
\text { are }\end{array}$ & $\begin{array}{c}\text { Adjuted } \\
\mathrm{R} \\
\text { Square }\end{array}$ & $\begin{array}{l}\text { Std Error } \\
\text { of the } \\
\text { Estimate }\end{array}$ \\
\hline 1 & .836 a & .699 & .690 & .73993 \\
\hline
\end{tabular}

Sumber : Output SPSS 17 a. Predictors: ( Constant ), X3, X1, $\mathrm{X} 2$

Dari tabel regresi linear berganda diperoleh koefisien determinasi $\left(\mathrm{R}^{2}\right)$ yaitu sebesar 0,699. Pengaruh variabel harga, pendapatan perkapita dan jumlah penduduk terhadap sektor rumah tangga dan non rumah tangga (Y) memberikan kontribusi sebesar $69,9 \%$, sedangkan sisanya sebesar $30,1 \%$ merupakan faktor lain.

6. Uji t

Tabel 6.

Coefficients $^{\mathrm{a}}$

\begin{tabular}{|c|r|c|c|c|c|}
\hline \multirow{2}{*}{ Model } & $\begin{array}{c}\text { Unstanda } \\
\text { rdized } \\
\text { Coefficie } \\
\text { nts }\end{array}$ & $\begin{array}{c}\text { Standardiz } \\
\text { ed } \\
\text { Coefficient } \\
\mathrm{s}\end{array}$ & $\mathrm{t}$ & $\mathrm{S}$ \\
\cline { 2 - 4 } & $\mathrm{B}$ & $\begin{array}{c}\text { Std. } \\
\text { Error }\end{array}$ & Beta & & \\
\hline 1 1 & & & & & \\
Consta & 1.043 & .491 & & 2.123 & .036 \\
$\mathrm{nt})$ & .287 & .116 & .285 & 2.485 & .015 \\
$\mathrm{X} 1$ & .271 & .127 & .265 & 2.131 & .036 \\
$\mathrm{X} 2$ & .347 & .130 & .330 & 2.664 & .009 \\
$\mathrm{X} 3$ & & & & & \\
\hline
\end{tabular}

Sumber : Output SPSS 17

a. Dependent Variable: Y

1) Uji parsial antara variabel bebas harga $\left(X_{1}\right)$ dengan sektor rumah tangga dan non rumah tangga (Y). dengan $t_{\text {hitung }}=2,485$

Prosedur pengujian uji $\mathrm{t}$ adalah mnggunakan uji 2 sisi $(\alpha=5 \%$ : $2=2,5 \%$ )

- Dengan df = n-k-1 = $100-3-$ $1=96$

- $\mathrm{t}_{\text {tabel }}=\mathrm{t}_{0.025(96)}=1,985$

- daerah kritis atau daerah penolakan $\mathrm{H}_{\mathrm{o}}$ 
Dari hasil uji $\mathrm{t}$ diperoleh $\mathrm{t}_{\text {hitung }}$ $>\mathrm{t}_{\text {tabel }}$ dengan nilai $2,485>$ 1,985, maka $\mathrm{H}_{\mathrm{o}}$ ditolak, yang berarti ada pengaruh yang signifikan antara variabel harga $\left(\mathrm{X}_{1}\right)$ terhadap sektor rumah tangga dan non rumah tangga (Y).

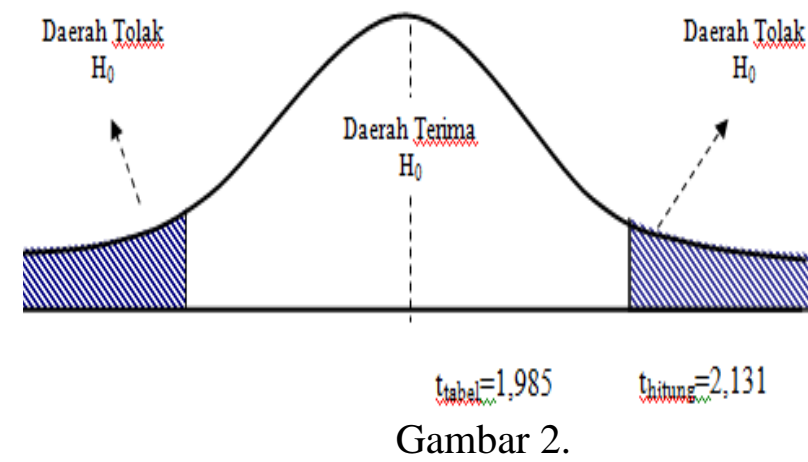

Daerah Penerimaan dan Penolakan

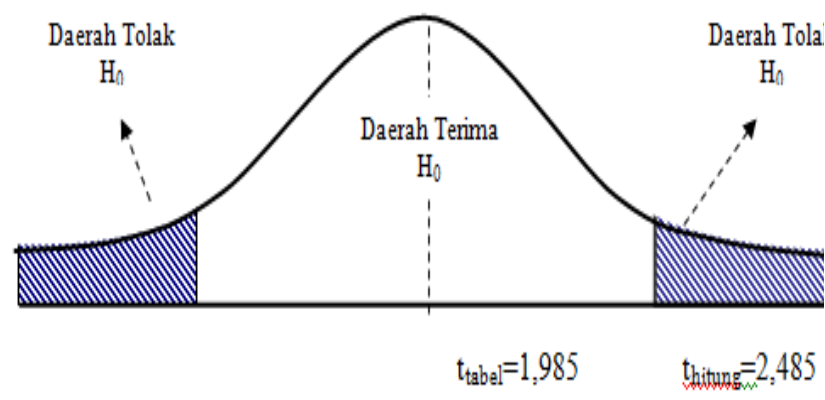

Gambar 1.

Daerah Penerimaan dan Penolakan

2) Uji parsial antara variabel bebas pendapatan perkapita $\left(\mathrm{X}_{2}\right)$ dengan sektor rumah tangga dan non rumah tangga $(\mathrm{Y})$. dengan $\mathrm{t}_{\text {hitung }}=2,131$

Prosedur pengujian uji $\mathrm{t}$ adalah mnggunakan uji 2 sisi $(\alpha=5 \%$ : $2=2,5 \%$ )

- Dengan df = n-k-l = $100-3-$ $1=96$

3) Uji parsial antara variabel bebas jumlah penduduk $\left(\mathrm{X}_{3}\right)$ dengan sektor rumah tangga dan non rumah tangga $(\mathrm{Y})$. dengan $\mathrm{t}_{\text {hitung }}=$ 2,664 Prosedur pengujian uji $\mathrm{t}$ adalah mnggunakan uji 2 sisi $(\alpha=5$ $\%: 2=2,5 \%$ )

- Dengan df $=\mathrm{n}-\mathrm{k}-\mathrm{l}=100-3-1=$ 96

- $\mathrm{t}_{\text {tabel }}=\mathrm{t}_{0.025(96)}=1,985$

- daerah kritis atau daerah penolakan $\mathrm{H}_{\mathrm{o}}$

Dari hasil uji $\mathrm{t}$ diperoleh $\mathrm{t}_{\text {hitung }}>$ $t_{\text {tabel }}$ dengan nilai 2,664 >1,985, maka $\mathrm{H}_{\mathrm{o}}$ ditolak, yang berarti ada pengaruh yang signifikan antara variabel jumlah penduduk $\left(\mathrm{X}_{3}\right)$ terhadap sektor rumah tangga dan non rumah tangga $(\mathrm{Y})$.

- $\mathrm{t}_{\text {tabel }}=\mathrm{t}_{0.025(96)}=1,985$

- daerah kritis atau daerah penolakan $\mathrm{H}_{\mathrm{o}}$

Dari hasil uji $\mathrm{t}$ diperoleh $\mathrm{t}_{\text {hitung }}$ $>t_{\text {tabel }}$ dengan nilai $2,131>$ 1,985, maka $\mathrm{H}_{\mathrm{o}}$ ditolak, yang berarti ada pengaruh yang signifikan antara variabel pendapatan perkapita $\left(\mathrm{X}_{2}\right)$ terhadap sektor rumah tangga dan non rumah tangga (Y).

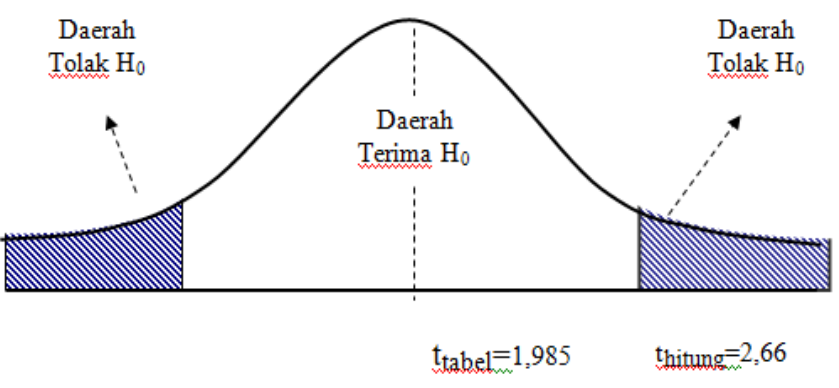

Gambar 3.

Daerah Penerimaan dan Penolakan 
7. Uji F

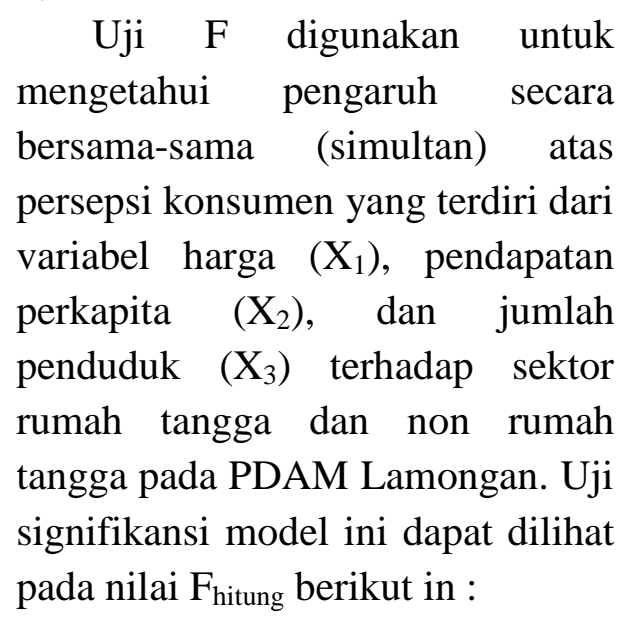

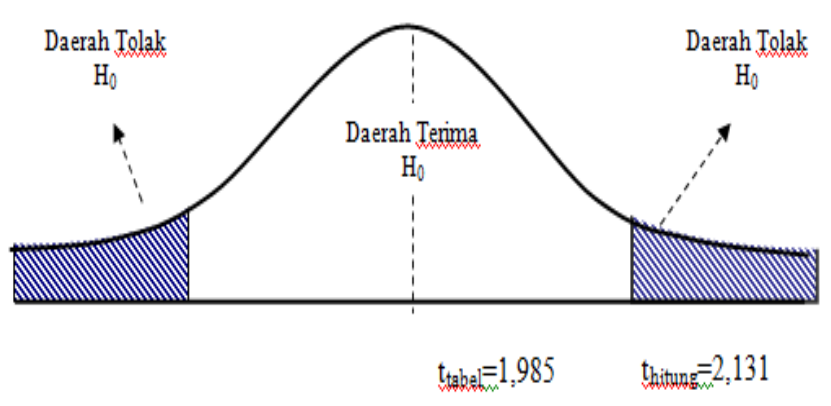

Gambar 4.

Daerah Penerimaan dan Penolakan

- Besarnya nilai $\mathrm{F}=\mathrm{Fa}(\mathrm{df}$ regresi, df residual $)=\mathrm{Fa}(\mathrm{k} ; \mathrm{n}-\mathrm{k}-$ 1)

- $\mathrm{F}_{\text {tabel }}=\mathrm{F}_{0.05(3 ; 96)}=2,699$

- $F_{\text {hitung }}=71,634$

- daerah kritis atau daerah penolakan $\mathrm{H}_{0}$

Dari hasil uji $\mathrm{F}$ diperoleh $\mathrm{F}_{\text {hitung }}$ $>\mathrm{F}_{\text {tabel }}$ dengan nilai $71,634>$ 2,699, maka $\mathrm{H}_{\mathrm{o}}$ ditolak, yang berarti ada pengaruh yang signifikan antara keseluruhan variabel bebas harga $\left(\mathrm{X}_{1}\right)$, pendapatan perkapita $\left(\mathrm{X}_{2}\right)$ dan jumlah penduduk secara simultan atau bersama-sama terhadap sektor rumah tangga

dan non rumah tangga (Y).

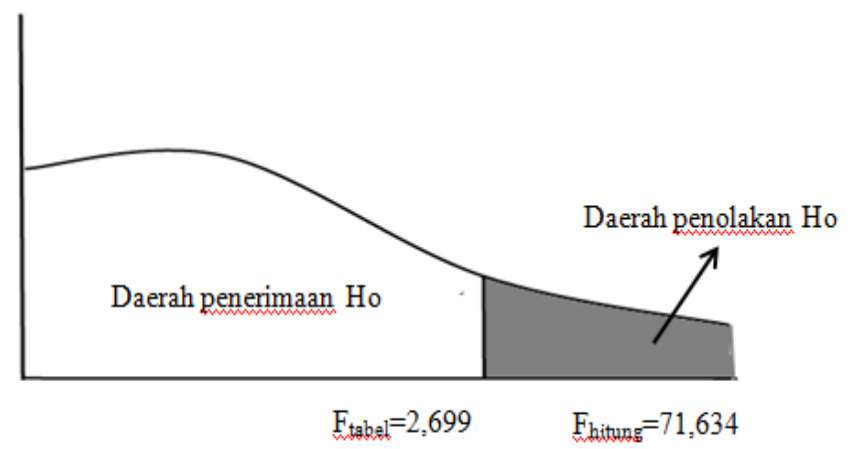

Gambar 5.

Daerah Penerimaan dan Penolakan

\section{KESIMPULAN DAN SARAN Kesimpulan}

Berdasarkan hasil analisis dan hasil pembahasan analisa tentang pengaruh trend, motif dan harga terhadap keputusan pembelian diperoleh kesimpulan sebagai berikut : 1. Dari uji $t$ diperoleh hasil $t_{\text {hitung }}$ variabel bebas sebesar harga $X_{1}=$ 2,485 , pendapaatan perkapita $X_{2}=$ 2,131 , jumlah penduduk $X_{3}=2,664$ $>t_{\text {tabel }}=1,985$,

2. Dari hasi perhitungan uji $F$ menjelaskan bahwa semua variabel bebas harga $\left(\mathrm{X}_{1}\right)$, pendapatan perkapita $\left(\mathrm{X}_{2}\right)$ dan jumalh penduduk $\left(\mathrm{X}_{3}\right)$ mempunyai pengaruh secara simultan (bersama-sama) terhadap variabel terikatnya yaitu sektor rumah tangga dan non rumah tangga (Y) dengan berdasarkan hasil perhitungan $\mathrm{F}_{\text {hitung }}>\mathrm{F}_{\text {tabel }}$ yaitu $71,634>2,699$. Sedangkan hasil dari uji determinasi dilihat dari besarnya variabel bebas terhadap sektor rumah tangga dan non 
rumah tangga sebesar 69,9\%, sedangkan sisanya sebesar $30,1 \%$ dijelaskan oleh variabel bebas yang lain yang tidak dimasukkan ke dalam model persamaan.

3. Hasil dari regresi linear berganda diperoleh persamaan, $\mathrm{Y}=1,043+$ $0,287 X_{1}+0,271 X_{2}+0,347 X_{3}$. Dari perhitungan tersebut, dapat diketahui bahwa variabel jumlah penduduk yang berpengaruh paling dominan terhadap sektor rumah tangga dan non rumah tangga karena variabel jumlah penduduk $\left(X_{3}\right)$ memiliki nilai yang besar dari variabel bebas yang lain.

\section{DAFTAR PUSTAKA}

Kotler dan Armstrong (2001: 439),

Pengertian Harga Definisi

Tujuan Faktor-faktor yang

Mempengaruhi Penetapan

Harga (Online),

http://www.landasanteori.com/

2015/07/pengertian-harga-

definisi-tujuan-faktor.html, di

akses 12 Desember 2015).

Merysa Rohma Dwi Sakina. 2008.

Analisis beberapa faktor yang mempengaruhi tingkat konsumsi air minum PDAM sektor rumah tangga dan non sektor rumah tangga di kota Surabaya

Sangadji, Etta Mamang dan Sopiah.

2013. Perilaku Konsumen.

Edisi 1. Yogyakarta : ANDI.

Sugiyono, 2012. Statistik untuk Penelitian. Cetakan ke-21. Bandung : Alfabeta.

Sugiyono, 2014. Metode Penelitian Kuantitatif, Kualitatif, R \& D”. Bandung : AlfaBeta
Sumarni, dan Suprihanto. 2014. Pengantar Bisnis. Edisi ke-6. Yogyakarta : Liberty

Sunyoto, Danang. 2013.Dasar-dasar Manajemen Pemasaran. Yogyakarta : CAPS.

Sunyoto, Danang. 2013.Perilaku Konsumen. Cetakan pertama. Yogyakarta : CAPS.

Yuni Masdayanti Harahap. 2011.

Faktor- faktor yang mempengaruhi permintaan air minum pada perusahaan daerah air minum PDAM Tirtanadi Medan 